\title{
DAMPAK PENDIDIKAN KEWIRAUSAHAAN MASYARAKAT (PKUM) DALAM KONTEKS PEMBERDAYAAN MASYARAKAT
}

\author{
Entoh Tohani \\ e-mail: tohani@uny.ac.id \\ Pendidikan Luar Sekolah, FIP Universitas Negeri Yogyakarta
}

JI. Colombo No.1, Daerah Istimewa Yogyakarta 55281

\begin{abstract}
Abstrak: Pendidikan kewirausahaan masyarakat (PKuM) diselenggarakan untuk membekali warga masyarakat terutama yang kurang beruntung dengan kemampuan berwirausaha yang dapat digunakan dalam rangka meningkatkan kualitas hidupnya. Penelitian studi kasus ini dilakukan untuk mengkaji dampak ekonomi dan sosial dari penyelenggaraan PKuM yang telah dilaksanakan. Penelitian yang dilaksanakan pada bulan April sampai dengan September 2014 ini merupakan penelitian kualitatif dengan kasus PKuM sebagai unit analisis penelitian yaitu program pendidikan Desa Vokasi yang dikembangkan oleh Kemendikbud yang telah dilaksanakan. Pengambilan data dilakukan oleh peneliti sendiri sebagai instrumen penelitian dengan menggunakan pedoman wawancara, observasi, dan dokumentasi. Analisis data dilakukan menggunakan teknik analisis data kualitatif. Untuk mencapai keabsahan data dilakukan triangulasi, dan perpanjangan pengamatan. Hasil penelitian menunjukkan, terdapat dampak positif terhadap kelompok sasaran walau masih dalam level individual. Oleh karenanya, PKuM yang akan dikembangkan perlu menekankan keberlanjutan dan akuntabilitasnya dalam upaya pemberdayaan masyarakat.
\end{abstract}

Kata-kata kunci: dampak, kewirausahaan, pendidikan nonformal, pemberdayaan.

\section{IMPACT OF COMMUNITY ENTREPRENEURSHIP EDUCATION (PKUM) IN THE CONTEXT OF COMMUNITY EMPOWEREMENT}

\begin{abstract}
Community Entrepreneurship Education (PKuM) aims at providing the community members to improve the quality of their life. This case study was conducted to identify the economic and social impacts of the PKuM. The research conducted as from April through September 2014 was a qualitative research with the case of PKUM as unit of analysis particularly education programs of Vocational Village developed by Ministry of Education and Culture. In collecting data, the researcher acted as the instrument using interview guides, observation sheets, and document study guide. The data were analyzed qualitatively. The reliability of the data was proved by triangulation and prolonging the observation. The research findings show the positive impacts to the target population though still at individual level. Therefore, the research suggests the PKuM to develop should emphasize its continuity and accountability in empowering the community.
\end{abstract}

Keywords: impact, entrepreneurship, non-formal education, empowerment

\section{PENDAHULUAN}

Pembangunan ekonomi suatu masyarakat pada dasarnya dimaksudkan untuk meningkatkan kualitas hidup dan kehidupan warga masyarakat melalui peningkatan pendapatan guna memenuhi kebutuhan ekonominya. Setiap masyarakat memiliki kebijakan pembangunan ekonomi yang berbeda-beda. Porter, et al. (2002) menyatakan bahwa pembangunan ekonomi dibedakan dalam tiga tahapan spesifik yaitu: (1) factor-driven stage, (2) effeciency-driven stage, dan (3) innovationdriven stage (Acs, et. al., 2008). Factor-driven stage merupakan perkembangan ekonomi yang didasarkan pada pemanfaatan sumberdaya alam dan manusia, dimana masih menghasilkan pendapatan yang rendah. Effeciency-driven stage ditandai dengan produksi jasa dan barang yang standar, dan lebih cenderung kegiatan ekonomi dalam tahap ini merupakan manufaktur dan kegiatan eksport. Sedangkan innovation-driven stage ditandai dengan kemampuan memproduksi barang dan jasa yang lebih inovatif dengan menggunakan teknologi mutakhir. Pada tahapan yang terakhir ini, kewirausahaan menjadi faktor penyebabnya dan memungkinkan lebih berkembang karena adanya perubahan teknologi selama periode perang dunia, dan terjaidnya penurunan di sektor manufaktur. 
Setiap masyarakat memiliki aktivitas kewirausahaan yang tidak sama. Survey yang dilakukan oleh General Entrepreneurship Monitor (GEM) pada tahun 2014 memposisikan Indonesia sebagai negara yang masih menekankan pada pengembangan ekonomi yang lebih didasarkan pada efesiensi dari proses pembangunan ekonomi (Singer, et al., 2015) yaitu negara yang pembangunan ekonominya menggunakan ketersediaan teknologi, pendidikan dan pelatihan di perguruan tinggi, efesiensi pasar produk, efesiensi pasar tenaga kerja, dan ukuran pasar. Artinya, Indonesia masih minim dalam menumbuhkembangkan aktivitas kewirausahaan dalam masyarakat baik terkait dengan pengembangan sikap berwirausaha, aktivitas wirausaha, dan kultur sosial untuk kewirausahaan. Hal ini menunjukkan bahwa pengembangan kewirausahaan di Indonesia perlu dikembangkan dengan mengedepankan pada pengembangan program kewirausahaan, transfer pengetahuan, kebijakan keuangan untuk kewirausahaan, norma dan sosial budaya yang kondusif, pengembangan inovasi, dan sebagainya. Untuk mengembangkan kewirausahaan, dapat dilakukan dengan menyelenggarakan pendidikan untuk kewirausahaan.

Terkait dengan hal tersebut dan dalam upaya mengembangkan kualitas masyarakat Indonesia dalam aspek ekonomi, berbagai bentuk pendidikan kewirausahaan masyarakat banyak diselenggarakan baik oleh instansi pemerintah, lembaga pemberdayaan masyarakat, maupun masyarakat sendiri yang diwujudkan dalam bentuk Kelompok Belajar Usaha (KBU), Kelompok Pos Pemberdayaan Keluarga (Posdaya), Kelompok Usaha Bersama (KUBe), program Pendidikan Kewirausahaan Masyarakat (KUM), program PMPM-Md, program Desa Produktif dan Gabungan Kelompok Tani (Gapoktan).

Secara khusus, Departemen Pendidikan Nasional melalui Direktorat Pembinaan Kursus dan Pelatihan menyelenggarakan program Pendidikan Kewirausahaan Masyarakat (PKM) yang digalakkan sejak tahun 2009. Adapun jumlah penyelenggara program pendidikan kewirausahaan masyarakat yang mendapatkan blockgrant tahun 2012 sekitar 40 lembaga/penyelenggara. Jumlah tersebut menurun apabila dibandingkan dengan penerima program pendidikan kewirausahaan tahun 2011 yaitu sebanyak 360 lembaga. Selain program PKM, digalakkan juga program Desa Vokasi yang berjumlah relatif banyak dan telah dirintis sejak tahun 2009. Program ini pada tahun 2012 berjumlah sebanyak 127 program, menurun dibandingkan dengan program yang didanai pada tahun 2011 yang mencapai 234 program (www.infokursus.net).

Pendidikan dimaknai sebagai upaya sadar untuk mengembangkan individu, kelompok, dan masyarakat agar memiliki nilai-nilai, keterampilan, dan pengetahuan yang berguna untuk mendapatkan kehidupan yang lebih baik. Salah satu tujuan pendidikan adalah menjadikan manusia memiliki kapasitas untuk melakukan kegiatan kreatif, menciptakan usaha sendiri, atau bekerja sama perusahaan dalam konteks memenuhi kebutuhan hidupnya yang meliputi kebutuhan primer, sosial, dan sebagainya. Hal ini berarti bahwa pendidikan harus menjadikan individu-individu memiliki kapasitas atau kompetensi kewirausahaan. Sebagaimana Drucker (1985) menyatakan bahwa kapasitas kewirausahaan dapat dibangun dengan pendidikan. Dengan kata lain, pendidikan kewirausahaan akan menjadi sarana atau alat untuk menciptakan sumber daya manusia untuk mengembangkan sistem ekonomi dan kesejahteraan masyarakat.

Secara teoretis, PKuM merupakan bentuk pendidikan kewirausahaan yang secara khusus diperuntukkan bagi warga masyarakat yang umumnya orang dewasa dan/atau marginal. Fayolle \& Gailly (2008) mengusulkan sebuah model pendidikan kewirausahaan yang dibagi menjadi dua tingkat, yaitu tingkat ontologis dan proses pendidikan. Tingkat ontologis menjelaskan tiga aspek pendidikan kewirausahaan: apa makna pendidikan kewirausahaan, apa makna pendidikan dalam konteks kewirausahaan, dan peranan pendidik dan peserta didik. Pendidikan kewirausahaan dipahami sebagai sebuah proses untuk mengembangkan kelompok sasaran (individu atau kelompok) menjadi orang yang kreatif, inovatif dan produktif yang mampu menemukan solusi dari masalah yang dihadapi dengan menggunakan sumber daya di lingkungan mereka baik sumber daya sosial dan sumberdaya alam.

Pendidikan kewirausahaan muncul karena perubahan sosial yang tidak menentu dan menuntut kompetensi kewirausahaan dimiliki oleh individu, organisasi dan masyarakat (Kirby, 2004:514). 
Peningkatan pendidikan kewirausahaan dapat disebabkan oleh: a) adanya permintaan dari perkembangan ekonomi, penciptaan pekerjaan, perluasan jejaring ekonomi, perubahan teknologi dan perubahan iklim politik, juga kemunculan inovasi; b) peserta didik memiliki peluang untuk bekerja mandiri atau self-employement dan mendapatkan karier profesional di setiap perusahaan ukuran apapun; dan c) perusahaan besar atau menengah menuntut staf mereka untuk mampu memiliki keterampilan manajerial baru dan perilaku (Fayolle, 2007:54).

Pada tingkat pendidikan, PKuM menyangkut aspek-aspek yang saling berkaitan, yaitu (a) tujuan pendidikan kewirausahaan, (b) kelompok sasaran, (c) kurikulum, (d) metode pendidikan, (e) pelaksanaan proses pendidikan, dan (f) evaluasi. Tujuan menjelaskan situasi yang direncanakan dan diharapkan untuk dapat dicapai, yaitu terwujudnya kompetensi kewirausahaan yang mencakup: kompetensi kognitif, kompetensi sosial, dan kompetensi yang berorientasi pada aksi/tindakan (Boyless, 2012:47). Senada dengan ini, Fayolle (2008) berpendapat bahwa pendidikan kewirausahaan memiliki tiga kategori yaitu tujuan meningkatkan kesadaran siswa, mengajarkan teknik, prosedur dan pemecahan masalah, dan mendukung proyek sebagai perusahaan mutual. Pikiran lain diperdebatkan oleh Mwasalwiba (2010:26) yang menunjukkan bahwa tujuan spesifik pendidikan kewirausahaan dapat dikelompokkan dalam belajar "tentang", belajar "untuk", belajar "melalui", dan belajar "dalam", juga programprogram pelayanan kepada masyarakat.

Penyelenggaraan PKuM diharapkan terlaksana secara efektif yaitu terjadinya peningkatan kesejahteraaan kepada individu, kelompok maupun masyarakat. Dalam hal ini, kelompok sasaran harus mampu menjadikan hasil pembelajaran yang telah dicapainya menjadi bermakna bagi kehidupannnya. Hasil pembelajaran yang dicapai bukan hanya sebagai sesuatu yang tidak berguna atau innerts idea, namun diaplikasikan dalam bentuk kegiatan wirausaha yang produktif dalam kehidupan seharihari baik secara individu maupun secara kelompok. Kegiatan produktif harus mampu memberikan keuntungan materi dan ekonomi bagi mereka.

Lebih jauh, hasil penerapan hasil belajar perlu diarahkan pada pengembangan peran sosial yang positif kelompok sasaran dalam kehidupan masyarakatnya seperti bertindak sebagai pengembang masyarakat dan pendidik masyarakat, dan peningkatan kontribusi yang positif pada kehidupan politik khususnya ikut berpartisipasi dalam pembangunan dan pengambilan keputusan dalam menghadapi masalah yang dihadapi bersama. Pendidikan kewirausahaan masyarakat perlu menghasilkan produktivitas, adaptabilitas, dan kontinuitasnya.

Dilihat dari aspek lain, PKuM yang berhasil atau efektif adalah memberikan umpan balik dan masukan, tentunya dicapai dengan melihat hasil evaluasi pendidikan ini, guna pengambilan keputusan untuk perbaikan kepada pihak terkait penyelenggaraan PKuM seperti para pengelola dalam rangka mengetahui kendala-kendala, perbaikan, dan/atau penghentian program pendidikan kewirausahaan; terhadap pendidik atau narasumber dalam rangka mengembangkan kemampuan melatih dan refleksi diri, dan bagi para donator atau pihak lain dalam rangka meningkatkan kualitas dan kuantitas partisipasi dalam menyukseskan proses pendidikan kewirausahaan (Linton \& Pareek, 1984).

Mendasarkan pada pemikiran di atas, maka dipandang perlu melakukan penelitian mengenai kebermanfaatan PKuM yang diselenggarakan terhadap kemajuan kelompok sasaran baik individu maupun masyarakat guna menghasilkan informasi yang bermanfaat untuk menjadi masukan pengembangan PKuM yang memiliki kontribusi positif pada keberhasilan pendidikan di masa yang akan datang dan guna menghasilkan efektivitas program pendidikan kewirausahaan masyarakat yang lebih besar terhadap kemajuan masyarakat.

\section{METODE PENELITIAN}

Penelitian yang dilakukan ini menggunakan pendekatan studi kasus yaitu penelitian yang bertujuan untuk menelaah mengenai "bagaimana" dan "mengapa" suatu aktivitas atau phenomena terjadi atau berlangsung (Yin, 2014:4). Dalam hal ini, penelitian dimaksudkan untuk mengkaji dampak pendidikan kewirausahaan masyarakat (PKuM) yang telah dilaksanakan terhadap peningkatan kualitas kelompok sasaran dan/atau masyarakat.

Penelitian ini dilaksanakan pada bulan April 
sampai dengan September 2014. Penelitian ini dilakukan terhadap unit analisis yang merupakan kegiatan pendidikan kewirausahaan masyarakat yang dikembangkan oleh Kementerian Pendidikan dan Kebudayaan. Unit analisis yang dikaji ini adalah desa Vokasi Gemawang sebagai rintisan yang dilaksanakan di Desa Gemawang, Kecamatan Jambu, Kabupaten Semarang, dan dua program Desa Vokasi yang merupakan imbas yang dilaksanakan masing-masing di Desa Sukoharjo, Kecamatan Margorejo, Kabupaten Pati, dan Desa Karangrandu, Kecamatan Pecangaan, Kabupaten Jepara. Ketiga unit analisis ini ditentukan secara bertujuan (purposive).

\section{HASIL DAN PEMBAHASAN}

Penelitian yang dilakukan ini mengkaji pendidikan kewirausahaan masyarakat dalam hal ini program pendidikan Desa Vokasi yang telah dilaksanakan. Melalui program pendidikan Desa Vokasi ini diharapkan dapat membentuk kawasan desa yang menjadi sentra beragam vokasi, dan terbentuknya kelompok-kelompok usaha yang memanfaatkan potensi sumberdaya dan kearifan lokal. Dengan demikian, warga masyarakat dapat belajar dan berlatih menguasai keterampilan yang dapat dimanfaatkan untuk bekerja atau menciptakan lapangan kerja sesuai dengan sumber daya yang ada di wilayahnya, sehingga taraf hidup masyarakat semakin meningkat (Ditbinsuslat, 2013:2).

Adapun program PKuM yang dikaji meliputi: (a) Desa Vokasi Gemawang yang ada di Kab. Semarang, (b) Desa Vokasi Sukoharjo, yang berada di Kabupaten Pati, dan (c) Desa Vokasi Karangrandu, di Kabupaten Jepara. Desa Vokasi Gemawang merupakan rintisan program PKuM yang dikembangkan pemerintah melalui P2PAUDNI Regional 2, dan kedua Desa Vokasi lainnya merupakan pengembangannya yang dilakukan oleh SKB setempat. Di Gemawang, terdapat aktivitas wirausaha yang sampai saat ini berjalan yaitu: usaha pembuatan baik, yang dikelola seorang pelaku usaha dengan 9 orang pekerja yang mana mayoritas pekerjanya adalah warga belajar yang pernah mengikuti PKuM, usaha kuliner/produksi makanan ringan yang dilakukan oleh 12 orang lulusan PKuM, dan pembuatan alat permainan edukatif yang dikembangkan oleh seorang lulusan PKuM dengan 5 orang pekerjanya. Di Karangrandu, terdapat kelompok kuliner "Sri Mulya" yang memiliki
Pengambilan data dilakukan oleh peneliti sendiri sebagai instrumen penelitian dengan menggunakan pedoman wawancara, observasi, dan dokumentasi. Subjek penelitian adalah mereka yang terlibat dan/atau mengetahui banyak mengenai penyelenggaraan pendidikan kewirausahaan masyarakat yaitu inisiator pendidikan kewirausahaan (P2PNFI, SKB), para pengelola, kelompok sasaran, narasumber, aparat pemerintahan desa, dan tokoh masyarakat. Analisis data dilakukan menggunakan teknik analisis data kualitatif. Sedangkan, untuk mencapai keabsahan data dilakukan triangulasi, dan perpanjangan pengamatan.

anggota sekitar 25 orang berusaha memproduksi makanan/kue basah. Di Sukoharjo, terdapat kelompok wirausaha budidaya pembibitan ikan lele dengan anggota sekitar 30 orang anggota.

PKuM yang dilaksanakan idealnya memberikan dampak yang diharapkan sesuai dengan tujuan yang ditetapkan baik bagi kelompok sasaran, organisasi penyelenggara, maupun masyarakat. Hasil penelitian berikut ini berusaha memaparkan mengenai dampak PKuM terhadap kemajuan dalam aspek ekonomi, sosial budaya, dan politik yang terjadi setelah pelaksanaan PKuM. Penyajian dampak PKuM dilakukan dalam paparan per PKuM maupun lintas PKuM.

1. Dampak PKuM Desa Vokasi Gemawang

Keberadaan PKuM desa vokasi Gemawang dipandang penting oleh warga masyarakat. Mereka memandang bahwa program desa vokasi sangat dibutuhkan karena dapat memberikan manfaat bagi masyarakat. Bs, Kepala Desa Gemawang menyatakan bahwa kebutuhan akan pendidikan bagi masyarakat merupakan dasar kebutuhan yang keberadaannya harus menjadi prioritas. Dari ketercapaian kebutuhan pendidikan tersebut, seterusnya akan membentuk pola pikir masyarakat yang berkualitas, yang nantinya akan berpengaruh terhadap sektor-sektor lain dalam kehidupan, termasuk perilaku produktifnya masyarakat dalam melakukan usaha di bidang ekonomi “...melalui program desa vokasi ini pendidikan masuk dalam bentuk pelatihan-pelatihan keterampilan, mengawali proses pemberdayaan terhadap masyarakat desa..." (Wawancara,15/9/2013). PKuM ini dipandang sebagai upaya mengatasi minimnya pengetahuan 
dan keterampilan yang dibutuhkan guna mengelola dan memanfaatan potensi yang ada di masyarakat. Berbagai potensi wirausaha yang ada di masyarakat sebelum PKuM desa vokasi masih belum optimal dimanfaatkan. Hal ini diindikasikan dengan produktivitas hasil usaha yang diperoleh warga masyarakat masih minim sebagaimana terjadi pada kelompok Tataboga yang mana sebelum dilaksanakan PKuM, para anggota mengalami kesulitan dalam memperoleh pendanaan untuk membeli peralatan produksi dan tidak memiliki pengetahuan yang baik dalam menghasilkan produknya.

PKuM desa vokasi yang telah dilaksanakan memberikan manfaat positif berupa peningkatan pendapatan bagi para anggota kelompok usaha produktif. Sut, sebagai ketua kelompok wirausaha tataboga, menjelaskan mengenai manfaat yang diperoleh melalui kelompok wirausaha yaitu dengan didapat bantuan berupa modal untuk pendanaan guna menjadikan usaha kelompok menjadi lebih maju (Wawancara, 20/10/2014). Pendapat senada disampaikan $\mathrm{Fz}$, ketua kelompok wirausaha batik yang menyatakan bahwa sekarang para anggota atau karyawan yang bekerjasama dengannya sudah mengalami peningkatan secara ekonomi misalnya dalam hal kemampuan menggunakan daya listrik dimana sebelum terlibat dalam kelompok banyak anggota kelompok hanya mampu memasang daya listrik 450 watt, dan setelah terlibat kelompok dirinya mampu memasah daya yang rata-rata sudah 2200 watt (Wawancara, 20/10.2014). Begitu pula perubahan pendapatan warga masyarakat terjadi pada kelompok APE yang memandang bahwa, sebagaimana dikemukakan oleh Mhn bahwa PKuM telah mampu meningkatkan pendapatan dari para pekerjanya dimana mereka mendapatkan rata-

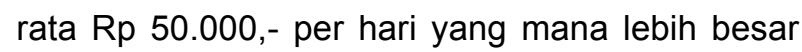
dibanding dengan penghasilan sebelum tergabung dalam kegiatan pembuatan alat permainan edukatif (Wawancara, 22/10/2014).

Pendapat lain dikemukakan oleh Zrf, sebagai anggota usaha produktif madu, yang menyatakan bahwa pembentukan pra-koperasi idealnya dapat diwujudkan agar lebih dapat memberikan kekuatan atau kemampuan berusaha bagi para anggota kelompok. Pra-koperasi dapat menjadi suatu wahana yang berfungsi untuk penetapan keseragaman harga penjualan, memudahkan memperoleh bantuan dari pihak luar, dan memungkinkan menjadi sarana simpan-pinjam yang dapat menguntungkan para anggota kelompok. Namun disayangkan karena muncul ketidakharmonisan dalam kelompok menyebabkan kelompok tidak dapat berjalan sesuai harapan, "...sekarang ini setiap anggota kelompok masih melakukan pekerjaannya sendiri-sendiri, adapun mereka saling membantu hanya pada waktu panen madu, mereka hanya membantu tenaga pengambilan madu..." (Wawancara, 20/10/2014).

Mendasarkan pada temuan di atas, disimpulkan bahwa PKuM desa vokasi Gemawang dipandang sangat penting untuk kemajuan ekonomi masyarakat. Ini dipandang menjadi upaya yang dapat membekali warga masyarakat dengan keterampilan dan pengetahuan berusaha guna melakukan usaha produktif. Terjadi perubahan kualitas kehidupan ekonomi anggota dan keluarganya sebagai hasil dari pemanfaatan keterampilan fungsional yang dimilikinya. Walaupun demikian, keberhasilan pemanfaatan keterampilan fungsional nampaknya tidak selalu sesuai harapan apabila sumberdaya yang mendukung untuk pengembangannya tidak dapat terakses baik karena ketidakmampuan mencapainya, keberadaan akses dan mekanisme yang sulit, atau karena perilaku individu-individu negatif.

Keberadaan PKuM desa vokasi pun memungkinkan tercipta kehidupan sosial masyarakat menjadi kondusif. Kelompok wirausaha berfungsi pula sebagai wahana untuk saling membelajarkan dan membina hubungan positif dengan orang lain. Hal ini terlihat dengan adanya pertemuan rutin antar anggota kelompok yang menjadi sarana untuk saling berbagi pengalaman dan saling membantu seperti pada kelompok wirausaha tataboga yang mana memungkinkan setiap anggota yang mengalami kesulitan dalam memperoleh bahan baku dapat memperoleh bahan baku berupa ubi singkong dengan meminjam bahan baku kepada anggota yang lain. Pertemuan rutin pun menjadi sarana untuk saling mengingatkan agar kelompok dan usaha masing-masing tidak mengalami kemunduran dana harus tetap terjaga keberlangsungannya. Selain itu, menurut Sut “...seringnya desa ini (Gemawang) dijadikan lokasi kunjungan dari orang-orang luar, produk keripik saya dapat terjual, mereka membeli kripik kami sebagai oleh-oleh..." (Wawancara, 20/10/2014). Pendapat senada dari pelaku usaha 
APE, yang memandang bahwa adanya program desa vokasi ini (APE) telah menjadikan dirinya mampu memberikan lebih dalam hal memberikan bantuan sosial kepada masyarakat selain telah memberikan masukan pendapatan yang cukup bagi para pekerjanya, “...malah apabila ada kegiatan kampung/desa, saya sering diminta sumbangan yang lebih besar dibanding warga masyarakat lainnya, mungkin karena dipandang berhasil dalam usaha..." (Wawancara, 22/10/20014).

Adanya hubungan yang baik dengan pengelola lokal dan para pelaku wirausaha menjadi suatu hal yang menguntungkan. Hubungan ini diwujudkan dalam bentuk pertemuan rutin dan melalui hubungan informal dalam kehidupan sehari-hari. Pertemuan antara kelompok yang diwakili oleh ketua masingmasing kelompok berjalan sebagaimana diharapkan berfungsi sebagai wadah dimana kelompok dapat berkoordinasi dengan pengelola lokal, saling berdiskusi mengenai permasalahan yang ditemukan, dan saling memberikan informasi terkait dengan kemajukan kelompok. Namun disayangkan, bahwa menurut Amn bahwa pertemuan ini sudah tidak terjadi secara rutin karena kesibukan pengelola lokal dan banyaknya anggota atau kelompok yang sudah tidak menekuni kegiatan usahanya (Wawancara, 21/10/2014).

Fungsi kelompok usaha nampaknya bukan semata-mata sebagai sarana untuk mencari keuntungan, namun juga dapat menumbuhkan rasa kebersamaan, saling mengenal, dan berbagi informasi diantara para anggotanya. Dalam kelompok dibentuk sikap dan perilaku untuk mementingkan kepentingan bersama dalam hal mencapai tujuan kelompok yang telah disepakati. Temuan penelitian menunjukkan bahwa kehidupan kelompok diwarnai oleh komitmen yang erat dari semua anggotanya. Kehadiran kelompok tidak sebatas menjadi wadah yang tidak memberikan manfaat besar kepada anggotanya.

Di bidang politik, keberadaan kelompokkelompok usaha produktif wirausaha yang ada di Desa Gemawang walau tidak besar mampu memberikan pengaruh pada dinamika partisipasi politik. Salah satunya adalah produk wirausaha batik yang mana batik yang berdesain "kembang kopi" telah menjadi icon kabupaten Semarang. Pemerintah Kabupaten Semarang sudah mengakui keberadaan motif tersebut dan sudah meminta memproduksi kain batik yang akan digunakan untuk para staf atau pegawai di lingkungan pemerintahan setempat. Hal lain adalah aktivitas-aktivitas wirausaha yang ada - beserta kegiatan pendidikan masyarakat yang lainnya - telah menyebabkan pengakuan positif baik di tingkat desa maupun di tingkat kabupaten. Aktivitas dimaksud dipandang menjadi kesempatan bagi pemerintah untuk dapat menarik kunjungan dari individu atau lembaga lain yang dapat menghasilkan manfaat ekonomi bagi kesejahteraan masyarakat melalui penyelenggaraan berbagai pameran produk-produk wirausaha yang ada secara runtin.

Mendasarkan pada uraian di atas, diperoleh gambaran bahwa kegiatan-kegiatan wirausaha produktif sebagai hasil dari PKuM mampu memberikan manfaat ekonomi berupa peningkatan pendapatan/penghasilan bagi anggota kelompok; dan memberikan manfaat sosial seperti rasa kebersamaan, saling mengenal, dan memberikan informasi selain dapat meningkatkan status sosial dalam masyarakat. Namun, manfaat yang dihasilkan belum dapat berimbas lebih besar terhadap kehidupan masyarakat setempat. Apa yang disebut dengan nurture effect dari PKuM masih belum optimal terjadi. Hal ini terlihat dari aktivitas wirausaha atau ekonomi yang ditimbulkan cenderung masih dalam satu aktivitas yang sama, masih minim menumbuhkan aktivitas-aktivitas ekonomi atau usaha yang lain.

2. Dampak PKuM Desa Vokasi Karangrandu

Keberadaan kelompok wirausaha kuliner Karangrandu dipandang memberikan perubahan berarti kepada para warga kelompok. Mereka memandang bahwa kegiatan kelompok telah memberikan peningkatan pendapatan bagi semua anggota, walaupun disadari berbeda-beda tingkat pendapatan yang didapat oleh masing-masing anggotanya. Menurut seorang dukuh setempat, berinisial Abd, keberadaan kelompok kuliner telah merubah pekerjaan beberapa anggota kelompok yang semula sebagai buruh tani atau buruh meubel menjadi pelaku usaha bisnis kuliner (Wawancara, 5/2014). Hal ini didukung oleh penyataan MuSy, yang merupakan single parent, bahwa penghasilan yang didapat dari hasil berjualan dan menjadi "juru masak" pada suatu waktu atau kesempatan di tempat hajatan atau kegiatan pesta lainnya yang diselenggarakan oleh anggota atau 
warga masyarakat dapat membantu membiaya berbagai kebutuhan ekonomi keluarga (Wawancara, 5/2014). Kedua pendapat dimaksud memberikan pemahaman bahwa pendidikan kewirausahaan yang diselenggaraan di wilayah Karangrandu memberikan manfaat berupa peningkatan pendapatan bagi para anggotanya.

Hal lain yang perlu diperhatikan adalah bagaimana keberadaan kelompok sasaran mampu meningkatkan kualitas ekonomi dari warga masyarakat sekitar. Artinya, peningkatan pendapatan atau penghasilan yang dirasakan oleh individu anggota kelompok juga dialami oleh warga masyarakat lain. Dalam upaya memberdayakan masyarakat di bidang ekonomi, sebagaimana fungsi pendidikan yaitu menjadikan individu menjadi lebih produktif (Noeng Muhadhjir, 2001), PKuM yang telah dilaksanakan ini belum mampu memberikan manfaat ekonomi kepada warga masyarakat di luar para anggota kelompok dan keluarganya. Hal ini diindikasikan dengan anggota kelompok yang mana sejak awal masih belum menjadikan warga masyarakat lainnya yang ingin bergabung dengan anggota. Manfaat ekonomi yang masih dalam skala kecil yang terjadi dalam kelompok wirausaha ini dapat disebabkan keterbatasan modal yang dibutuhkan anggota kelompok. Walaupun ada kesadaran bahwa para anggota kelompok wirausaha membutuhan modal, keberanian dalam mencari sumber pendanaan atau modal masih belum muncul. Mereka memandang bahwa kelompok belum berani mengambil resiko untuk meminjam pendanaan dari luar, dan tidak terbiasa dalam mengelola pendanaan yang besar sebagaimana $\mathrm{Nt}$ menyatakan '...kami belum berani mengajukan pinjaman yang besar ke pihak lain..." (Wawancara, 17/7/2014).

Hal berbeda disampaikan oleh kepala Unit Pelaksana Teknis (UPT) BKK Kecamatan berinisial Hdy bahwa keberadaan kelompok wirausaha ini sedikit banyak telah menjadikan para anggota memiliki kesibukan berusaha secara perorangan, namun disadari untuk menjadikan mereka pelaku usaha yang profesional, “...mereka kurang menginternalisasi atau memiliki jiwa wirausaha yang sungguh-sungguh, sulit membentuk jiwa wirausaha dari kelompok masyarakat yang marginal, namun kami selalui memotivasi mereka..." (Wawancara,17/7/2014).
Dalam aspek sosial, keberadaan kelompok memberikan manfaat bagi para anggotanya. Adanya kegiatan arisan yang dilakukan setiap sebulan sekali memberikan nuansa kebersamaan antara para anggota, bahkan dengan para petugas dari BKK. Mereka merasakan nuansa kekeluargaan yang lebih baik, rasa persaudaraan yang lebih baik, dan tumbuhnya perasaan senang. Kegiatan arisan pun dapat menjadikan mereka menjadi lebih peduli pada sesama yang diwujudkan dalam bentuk saling mengunjungi apabila ada salah satu anggota yang mengalami musibah dan atau kepentingan lain. Hal lain adalah tumbuhnya sikap saling membantu di antara mereka, yang mana diwujudkan dalam perilaku saling pinjam alat produksi dalam pembuatan kuliner apabila salah seorang anggota memerlukan alat produksi tertentu. Anggota kelompok dapat meminjam alat produksi yang dimiliki kelompok atau alat produksi yang dimiliki masing-masing anggota. Dalam peminjaman, tidak ada kewajiban untuk membayar sewa alat, namun hanya diharapkan alat yang dipinjam tetap dalam keadaan baik. Selain itu, kehadiran petugas BP2KB setempat dipandang positif para anggota lebih mengenai memahamai mengenai kesehahatan reproduksi dan keluarga yang bahagia.

$\mathrm{Hal}$ di atas menunjukkan bahwa kelompok nampaknya memiliki interaksi antar anggota yang erat dan perilaku saling membantu cukup menggembirakan. Hal ini menunjukkan fungsi sosial dari kelompok sudah terjadi, namun masih terjadi dalam hubungan internal kelompok. Dalam konteks pengembangan kegiatan usaha, terlihat bahwa hubungan saling membantu dalam memajukan usaha masih sebatas pada semua anggotanya. Dalam hal ini, bantuan kepada warga masyarakat lain di luar kelompok terkait dengan kegiatan memajukan usaha yang ditekuni masih belum banyak dilakukan, padahal fungsi kelompok dalam memberdayakan masyarakat lain harusnya terjadi.

Keberadaan kelompok memberikan pengaruh pada pengambilan keputusan di tingkat lokal atau desa. Dalam konteks pengambilan keputusan di pemerintahan desa, kelompok yang diwakili oleh para pengurusnya sering dilibatkan. Kelompok diminta saran atau pemikiran mengenai rencana kegiatan yang akan diselenggarakan di wilayah pedesaan misalnya pameran kuliner yang diselenggarakan setiap satu tahun sekali, dan kegiatan menyamput 
perayaan hari besar baik wilayah maupun nasional. Hal lain adalah keberadaan kelompok telah menarik perhatian dari instansi terkait misal BKKBN yang selalu melakukan pendampingan kepada kelompok sekaligus menjadikan kelompok menjadi wadah atau sarana untuk menyebarkan informasi terkait dengan kesehatan repoduksi dan kesejahteraan keluarga.

Mendasarkan pada temuan di atas, dapat dikemukakan bahwa keberadaan kelompok dapat memberikan manfaat yang bermakna bagi para anggotanya berupa peningkatan pendapatan walau peningkatan pendapatan dimaksud masih relatif kecil terjadi pada warga masyarakat di luar kelompok. Kelompok pun menjadi tempat bagi para anggotanya untuk saling membantu dan bekerja sama sekaligus saling berbagai pengetahuan mengenai kegiatan usaha dan kesehatan reproduksi dan keluarga. Hal lain adalah sumbangsih kelompok sudah dapat dirasakan dalam proses pengambilan keputusan di masyarakat setempat. Namun demikian, keberadaan kelompok idealnya menjadi suatu wahana dalam memberdayakan warga masyarakat secara keseluruhan.

\section{Dampak PKuM Desa Vokasi Sukoharjo}

Kelompok budidaya bibit ikan lele "Tirtorejo" saat ini memiliki anggota sejumlah 20 orang dengan masing-masing anggota memiliki tempat budidaya ikan lele yang berbeda-beda luas dan jumlahnya dan dikelola oleh mereka sendiri. Mereka menghasilkan bibit ikan lele yang beragam sesuai dengan kebutuhan para konsumen bibit ikan lele. Dalam hal ini, tidak ada keharusan dari kelompok kepada setiap anggota untuk menentukan jenis bibit ikan lele apa yang akan dibudidayakan. Dengan kata lain bibit ikan lele yang dihasilkan akan berbeda sesuai dengan kemampuan masing-masing anggota kelompok.

Mekanisme pemasaran bibit ikan lele ke konsumen tidak diatur dalam kelompok. Artinya, setiap anggota kelompok memiliki kebebasan dalam menjual hasil budidayanya. Penjualan bibit ikan lele dilakukan melalui mekanisme yaitu: para anggota langsung menjual ke petani ikan lele (pembesaran lele), para anggota langsung menjual ke para bakul atau pengepul bibit ikan lele, dan para anggota melalui anggota lain menjual ke bakul atau para peternak pembesaran ikan. Yang terakhir dilakukan apabila bibit ikan lele yang dipesan oleh bakul atau peternak pembesaran ikan lele kepada salah seorang anggota tidak tersedia dan anggota bersangkuatan memberikan informasi mengenai ketersediaan bibit ikan lele yang dimiliki anggota lain. Hal yang ditekankan dalam proses penjualan adalah khusus untuk penjualan ke bakul, para anggota hanya menjual kepada bakul yang sudah sering dan dikenal oleh para anggota. Hal ini dilakukan karena khawatir perilaku negatif dari para bakul misalnya mempromosikan kejelekan bibit yang dihasilkan. Namun demikian, walaupun ada kebebasan dalam menjual baik menjual ke konsumen langsung maupun ke bakul, anggota menggunakan harga penjualan bibit yang seragam atau ukuran standar sesuai dengan ukuran bibit lele yang akan dijual sehingga terhindar dari persaingan yang tidak sehat antar anggota yang akhirnya menghancurkan usaha yang ditekuni. Sudah dipahami bahwa harga jual bibit ikan lele kepada para bakul relatif lebih rendah dibanding menjual langsung kepada para petani pembesaran ikan lele.

Keberadaan kelompok budidaya bibit ikan lele telah memberikan manfaat finansial yang baik terhadap kehidupan keluarga para anggotanya. Para anggota memandang mereka memiliki pendapatan yang relatif mencukupi di samping kegiatan lain sehingga meningkatkan kesejahteraan ekonomi. Hasil penelitian menunjukkan adanya salah seorang anggota menyatakan bahwa penghasilan sebesar Rp 3.000.000,- per bulan dari usaha pembibitan. Hal senada dinyatakan oleh Trm bahwa karena memiliki kolam pembibitan yang cukup banyak yang mana memerlukan modal awal sebanyak kurang lebih Rp 30 juta dalam sebulan, keuntungan bersih yang diperoleh adalah sekitar Rp 10 juta. Jaj sebagai salah satu anggota kelompok yang berasal dari Cirebon menyatakan “...pekerjaan ini sudah menjadi pekerjaan pokok yang sampai ini saya geluti, kebutuhan keluarga, sekolah anak didanai dari usaha ini..." (Wawancara, 29/03/2014). Bahkan beberapa orang diantara anggota kelompok telah mampu mempekerjaan warga masyarakat dalam melakukan kegiatan usahanya. Artinya, anggota kelompok membayar tenaga kerja yang dipekerjakannya. Melihat pernyataan kedua informan tersebut menunjukkan bahwa pendidikan kewirausahaan yang dilakukan telah memberikan manfaat ekonomi yang relatif baik bagi para anggota kelompok.

Perilaku saling membantu dan anjang sana 
nampaknya memberikan kepuasan kepada semua anggota. Mereka menganggap bahwa dalam kehidupan berkelompok terjadi rasa persaudaraan yang lebih kuat antar anggota kelompok, selain dengan sesama warga masyarakat lainya. Kehidupan usaha secara berkelompok dipandang mampu membangun rasa kebersamaan dalam berusaha dimana apabila usaha secara mandiri. Mereka memandang bahwa berkelompok memberikan kemudahan dalam kegiatan pembudidayaan bibit ikan lele, Dn (Wawancara, 29/03/2014) menyatakan dengan berkelompok dirinya mudah untuk bertanya kepada teman dan berbagi pengalaman baik berhasil maupun gagal dalam berusaha; serta mengindari perilaku negatif yang dapat merugikan orang lain.

Keberadaan kelompok mendatangkan perhatian yang besar dari pemerintah desa setempat. Pemerintah desa menganggap kelompok budidaya bibit ikan lele menjadi suatu wadah untuk memajukan kualitas hidup masyarakat di lingkungannya, sebagai media untuk mengatasi masalah kemiskinan yang ada di masyarakat. Pemerintah menyambut baik setiap kegiatan yang akan dilakukan dalam rangka mengembangkan kelompok dimaksud. Pada saat ada kegiatan penilaian mengenai kelompok budidaya ikan yang berprestasi, pemerintah desa memfasilitas penyelenggaraan kegiatan tersebut. Selain itu, aparat desa selalu memberikan motivasi pada kesempatan-kesempatan tertentu kepada semua anggota kelompok. Walau disadari bahwa pemerintah desa setempat belum mampu memberikan bantuan pendanaan karena keterbatasan sumberdaya yang dimiliki desa.

\section{Analisis Dampak Lintas PKuM}

PKuM yang telah diselenggarakan mampu memberikan manfaat positif terhadap kesejahteraan kehidupan masyarakat. Dalam aspek ekonomi, penyelenggaran PKuM yang dilaksanakan mampu memberikan manfaat berupa peningkatan keterampilan berwirausaha masing-masing anggota yang digunakan untuk bekerja dan akhirnya mampu meningkatan pendapatannya. Ketiga PKuM yang dikaji mampu menyebabkan terjadinya peningkatkan pendapatan anggota walaupun peningkatan pendapatan yang dicapai masih relatif kecil untuk meningkatkan pendapatkan di lingkungan masyarakatnya. Hanya pada kelompok PKuM pembibitan lele yang sudah mulai merintis usaha pembuatan kerupuk berbahan baku ikan lele bagi para ibu rumah tangga yang ada di dusun Gambiran.

Dalam aspek kehidupan sosial, nampak dalam ketiga kelompok wirausaha yang diteliti dapat dipahami bahwa kegiatan bersama mampu meningkatkan rasa saling membantu, kerja sama, dan tolong menolong dalam mengembangkan usaha masing-masing. Walau disadari, hal positif dimaksud masih berfokus pada kelompok dan masih kurang terjadi atau dirasakan oleh warga masyarakat di luar kelompok usaha. Sedangkan pada aspek politik, keberadaan usaha wirausaha yang ada telah memberikan hal positif bagi kemajuan masyarakat. Terdapat pengakuan dari pemerintah lokal mengenai urgensi kelompok dalam memberdayakan warga masyarakat, peran anggota kelompok dalam proses pengambilan kebijakan lokal, dan peningkatan partisipasi anggota kelompok dalam memajukan kehidupan masyarakatnya. Dampak PKuM yang dikaji secara lintas PKuM tersaji dalam tabel 1 .

Tabel 1. Agregat Dampak PKuM Desa Vokasi

\begin{tabular}{|c|c|c|c|}
\hline \multirow{2}{*}{$\begin{array}{l}\text { Kasus } \\
\text { PKuM }\end{array}$} & \multicolumn{3}{|c|}{ Dampak PKuM } \\
\hline & Aspek Ekonomi & Aspek Sosial & Aspek Politik \\
\hline Gemawang & $\begin{array}{l}\text { - Peningkatan pendapatan keluarga } \\
\text { dan masyarakat }\end{array}$ & $\begin{array}{l}\text { - Peningkatan kohesi antar anggota } \\
\text { - Saling membantu } \\
\text { - Peningkatan status social }\end{array}$ & $\begin{array}{l}\text { - Pengakuan pemerintah lokal } \\
\text { - Partisipasi material meningkat } \\
\text { - Keterlibatan aktif di masyarakat }\end{array}$ \\
\hline Karangrandu & - Peningakan pendapatan keluarga & $\begin{array}{l}\text { - Peningkatan kesehatan reproduksi } \\
\text { - Saling membantu antar anggota }\end{array}$ & $\begin{array}{l}\text { - Partisipasi dalam pengambilan } \\
\text { kebijakan pemerintahan lokal }\end{array}$ \\
\hline Sukoharjo & $\begin{array}{l}\text { - Peningakan pendapatan keluarga } \\
\text { - Percontohan ekonomi dari luar } \\
\text { - Merintis kuliner lele (krupuk) bagi } \\
\text { IRT }\end{array}$ & $\begin{array}{l}\text { - Anjang sana } \\
\text { - Saling membantu } \\
\text { - Saling memberikan informasi }\end{array}$ & - Pengakuan pemerintah lokal \\
\hline
\end{tabular}

Pendidikan nonformal memberikan manfaat terhadap masyarakat baik pada dimensi individu maupun pertumbuhan kolektif (Preece, 2010) sebagaimana dalam gambar 1 . Pada outcome level 
individu, pendidikan nonformal memberikan manfaat (1) sosialisasi ke dalam tata kehidupan yang ada (status quo) walaupun dapat pula berkontribusi pada pertumbuhan masyarakat sebagai suatu faktor skunder, serta (2) mengembangkan pertumbuhan individu dan rasa percaya diri (self esteem) dan para level masyarakat yang mana pendidikan lebih bersifat kolektif ditujukan untuk perubahan kolektif dan transformasi sosial, yang mana ini pun berkontribusi pada pertumbuhan individu dan partisipasi masyarakat. Misalnya, Kuenzi (2005) menyatakan manfaat pendidikan nonformal yang mencakup: menggerakkan orang untuk mengatasi masalah masyarakat, memiliki organisasi masyarakat, membangun kepemimpinan dalam organisasi, melaksanakan pertemuan tentang pekerjaan, dan membahas masalah/isu bersama, dan muncul organisasi masyarakat yang dimiliki warga masyarakat (Preece, 2010).

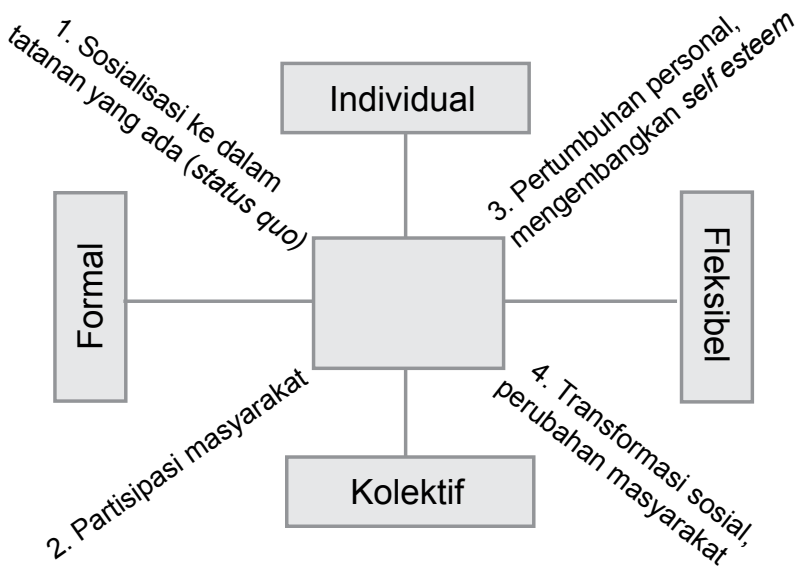

Gambar 1. Dampak pendidikan (Preece, 2010)

Hasil kajian menunjukkan bahwa penyelenggaraan PKuM yang dilakukan pada masing-masing kelompok sasaran dapat tercapai walaupun dalam tingkat capaian yang berbeda. Secara umum, dalam aspek ekonomi, penyelenggaraan PKuM dapat memberikan keterampilan yang digunakan untuk berkarya dan akhirnya dapat mendatangkan pendapatan yang dibutuhkan untuk meningkatkan kesejahteraan kualitas diri dan keluarganya. Sedangkan dalam aspek sosial, penyelenggaraan PKuM pun mampu memberikan pemahaman mengenai perilaku sehat, menimbulkan rasa senang, menimbulkan rasa solidaritas, dan kepedulian di antara para anggota atau kelompok sasaran. Namun demikian, penyelenggaraan PKuM yang dikembangkan masih kurang dapat memberikan manfaat pada perubahan atau transformasi sosial yang positif, artinya manfaat PKuM yang dicapai sebatas pada keberfungsian individual.

Memang disadari bahwa penyelenggaraan PKuM sebagai kegiatan investasi dalam pengembangan sumberdaya manusia tidak dengan sendirinya secara linear mendatangkan manfaat kepada pihak terkait. Hal ini menunjukkan bahwa dampak yang dihasilkan dari aktivitas pendidikan (PKuM) sangat dipengaruhi oleh beberapa faktor yang mempengaruhinya misalnya kesulitan mengubah pola pikir kelompok sasaran, perilaku kurang berani mengambil resiko, perubahan iklim, kepemimpinan dan pengelolaan yang tidak sehat. Sebagaimana Cross (1991) dalam Mutayanjulwa (2010) memberikan gambaran bahwa hambatan dalam pelaksanaan aktivitas pendidikan mencakup: a) hambatan situasional seperti kekurangan dana/uang, kekurangan waktu karena pekerjaan atau tanggungjawab domestik, dan kesulitan transportasi; b) hambatan institusional mencakup praktek atau prosedur yang membatasi kelompok sasaran berpartisipasi dalam proses penentuan program, kurang relevan dengan kebutuhan kelompok sasaran, dan waktu belajar yang terlalu penuh atau rigid; dan c) hambatan disposional yang terkait dengan sikap dan persepsi mengenai diri mereka misal terlalu tua untuk belajar, kurang percaya diri karena minim pendidikan yang dicapai sebelumnya, sikap bosan bersekolah dan aspek budaya/tradisional.

Dapat dikatakan bahwa untuk menghasilkan dampak yang besar baik bagi individu maupun masyarakat, PKuM yang akan diselenggarakan perlu mempertimbangkan bahwa bukan hanya semata-mata mempertimbangkan terwujudnya program PKuM yang dipandang tepat bagi kelompok sasaran, namun pula mempertimbangkan keberadaan dan keberfungsian energi sosial yang dapat menjadi penentu keberhasilan PKuM baik pada level kelompok sasaran dan masyarakat. Hasil kajian Biau \& Alpama (2009) menunjukkan bahwa ketidakadaan energi sosial yang terbangun dalam wujud kekurangotpimalkan pelaksanaan kegiatan pendidikan nonformal karena kurang optimal partisipasi kelompok sasaran (Preece, 2009). Hal ini dapat memberikan pengertian bahwa PKuM dipengaruhi oleh aspek sosial dan kultur 
suatu masyarakat, sebagaimana dipahami bahwa energi sosial muncul dari perilaku berinteraksi dalam masyarakat. Pemanfaatan energi sosial dalam PKuM menunjukkan bahwa pengembangan masyarakat yang dilakukan baik oleh pemerintah, masyarakat atau organisasi, perlu menekankan pada kearifan lokal, sebagaimana harapan dalam pengembangan masyarakat yang akhir-akhir ini mengurangi adanya penggunaan kebijakan desentralisasi pembangunan, dan menuju pada kebijakan pembangunan yang memperhatikan potensi dan masalah lokal atau endegenous developement.

\section{PENUTUP}

\section{Kesimpulan}

PKuM yang telah diselenggarakan meliputi PKuM rintisan yaitu PKuM yang dilaksanakan di Dea Gemawang, Kab. Semarang, dan dua PKuM pengembangan yang dilaksanakan di Desa Karangrandu, Kab. Jepara dan di Desa Sukoharjo, Kab. Pati. Ketiga PKuM yang telah diselenggarakan mampu memberikan manfaat kepada kelompok sasaran yang memiliki keinginan kuat untuk maju dan berusaha menerapkan kemampuan berwirausaha yang telah dimilikinya walaupun dalam tingkat pencapaian yang berbeda. Pada level individu, manfaat dimaksud mencakup: 1) aspek ekonomi yaitu terjadinya peningkatan pendapatan bagi individu pelaku wirausaha, keluarga, dan para pekerjanya; dan masih sedikit pelaku usaha yang mengembangkan usaha produktif untuk warga masyarakat sekitar, 2) aspek sosial berupa peningkatan kepedulian terhadap lingkungan dan terbangunnya rasa kohesivitas sosial diantara pelaku wirausaha pada masing-masing kelompok sasaran; dan 3) dalam aspek politik, walau tidak semua pelaku usaha, keberadaan pelaku usaha telah mampu membangun citra positif lingkungan masyarakatnya dan ikut berpartisipasi dalam penentuan kebijakan pemerintahan lokal. Pada level masyarakat, keberadaan PKuM belum dapat menyebabkan transformasi sosial yang positif dalam kehidupan masyarakat misalnya bermunculan aktivitas pemberdayaan masyarakat yang lain.

\section{Saran}

Berdasarkan pada hasil penelitian, pembahasan, dan kesimpulan sebagaimana telah dikemukan, maka beberapa saran dapat dikemukakan berikut: pertama, bagi pengelola desa vokasi gemawang, perlu membangun kembali jejaring kerja sama dengan para pengelola agar keberfungsiannya muncul kembali dan lebih menjadi penggerak masyarakat secara umum; kedua, kelompok wirausaha sebaiknya memiliki aktivitasi ekonomi bersama yang beragam untuk lebih memberda-yakan masyarakat dengan memunculkan aktivitas ekonomi yang memiliki keunggulan yang baik, lebih proaktif dalam mengembangkan kerja sama dalam rangka memperoleh sumberdaya dari pihak luar; dan selalu mengembangkan kebersamaan dalam kelompok; ketiga, pemerintah baik lokal maupun regional sebagai pendamping atau fasilitiator perlu memberikan kegiatan fasilitasi yang lebih bermanfaat dan berkelanjutan bagi kemajuan kelompok usaha; dan keempat, bagi masyarakat yang termotivasi berusaha mandiri dapat mengambil pelajaran dari keberhasilan pelaku usaha.

\section{PENUTUP}

Acs, Z. J., et al. (2008). "Entrepreneurship, economic development and institutions". Small Business Economics, Vol. 31. No. 3. Special Issue: Entrepreneurship, economic development and institutions (October 2008). pp. 219-234.

Boyless, T. (2012). "21'st century knowledge, skills, and abilities and entrepreneurial competenies: A model for undergraduate entrepreneurship education". Journal of Entrepreneurship Education, 15, 41-55. ProQuest Research Library.

Drucker, P. F. (1984). Innovation and entrepreneurship. California: Perfect Bound.
Kirby, D. A. 2004). "Entrepreneurship education: can business schools meet the challenge?". Journal of education training, 46, 510-519.

Lynton P., \& Pareek, U. (1984). Pelatihan dan pengembangan tenaga kerja. Terjemahan. Jakarta: PT. Pustaka Binaman Pressindo.

Muntayanjulwa, E. (2011). Nonformal education in development countries: Participation and activities of women groups in Uganda-East Africa. Saarbrucken: LAPLAMBERT Academic Publishing.

Mwasalwiba, E. S. (2010). Entrepreneurship edu- 
cation: A review of its objectives, teaching methods, and impact indicators. Education + Training, 52, 20-47.

Preece. (2009). Nonformal education, proverty reduction, and life enhancement: A comperative study. Gabarone; Lentswe La Lesedi, Ltd.
Singer, S., Amoros, J.E., \& Arreola, D.M. (2015). Global entrepreneurship monitor 2014 global report. London: Global Entrepreneurshiop Research Association.

Yin, R. (2014). Case study research: Design and methods. Los Angeles: Sage Publication, Inc. 